\title{
A Hidden Community: Justifying the Inclusion of Roma As an Ethnic Identity in the 2021 Scottish Census
}

\author{
Nicola Hay \\ Nicola.Hay@uws.ac.uk \\ $\mathrm{PhD}$ candidate and Associate Lecturer, University of the West of Scotland \\ ORCID: https://orcid.org/0000-0001-6425-5326
}

Nicola Hay is a PhD candidate exploring Roma, Gypsy, and Traveller students' agency, educational progression, and career decision-making in the United Kingdom. She is also an Associate Lecturer across a range of modules including Sociology, Gender Studies, Social Policy, and Global Society at the University of the West of Scotland. Nicola also sits on the Committee of Show Racism the Red Card Scotland and serves as an education adviser for the Gypsy Roma Traveller Police Association.

\section{Luke Campbell}

Luke.Campbell@Glasgow.ac.uk

Associate Tutor of Community Development, University of Glasgow

ORCID: https://orcid.org/0000-0003-3590-8505

Luke Campbell is a queer working-class community worker based in West Pilton. Born in Paisley and having grown up in Dundee, he has spent the last seven years working across the Scottish central belt addressing social inclusion, supporting anti-hate crime initiatives, and promoting adult education. He currently teaches community development on a part-time basis at the University of Glasgow; runs a community hub in Edinburgh; and is undertaking a PhD on how lone parents have sought to navigate and survive austerity. Twitter: @chainuptheswing

\section{Colin Clark \\ Colin.Clark@uws.ac.uk}

Professor of Sociology and Social Policy, University of the West of Scotland

ORCID: https://orcid.org/0000-0002-6028-5197

Professor Colin Clark teaches Sociology and Social Policy at the University of the West of Scotland. He lives in Glasgow and is a Board Director for the Coalition for Racial Equality and Rights and a Trustee of Romano Lav (Roma Voice). Colin also acts as a research adviser for the Scottish Human Rights Commission, the Traveller Movement, and the Advisory Council for the Education of Romanies and other Travellers. Twitter: @profcolinclark

\section{Marta Kowalewska \\ Marta.Kowalewska@ed.ac.uk \\ PhD candidate, University of Edinburgh \\ ORCID: https://orcid.org/0000-0003-2661-6965}

Marta Kowalewska is a PhD candidate and graduate teaching assistant in Sociology at the University of Edinburgh. Her work uses intersectional feminist methodologies to explore the politics of knowledge production, epistemic injustice, and epistemic resistance in relation to Roma communities in East Central Europe, focusing on Poland in particular.

\section{Lynne Tammi}

lynne@ayeright.scot

ORCID: https://orcid.org/0000-0001-5224-8540

Dr Lynne Tammi is a freelance consultant and independent researcher on Human Rights and Equalities. Her academic interests and work focus on the social representations of groups and communities living on the peripheries.

\section{Brigitta Balogh}

Brigitta.Balogh@city.ac.uk

Bar Professional Training Course student, City, University of London

ORCID: https://orcid.org/0000-0002-8671-1705

Brigitta Balogh is a Bar Professional Training Course student at City, University of London. She is a Romani rights advocate who organized a parliamentary event to commemorate Romani Resistance Day in Westminster while also launching a 10-point action plan to achieve better outcomes for Roma in the United Kingdom. She also has also called for law reform, endorsed by academics, legal professionals, and organizations, before being submitted to Lord Bourne. Brigitta was also named as one of the women of the future by Hungarian National Geographic in 2019. 


\section{Abstract}

This article investigates the invisibility of Roma communities within Scottish census ethnic monitoring categories and broader empirical data. Consistent negative stereotyping as well as systematic oppression within social policy, dominant discourses, and data collection processes excludes Roma from participatory citizenship. This article identifies precise forms of marginality and invisibility within official government data - permeated through social and education policy - that thereby limit the effective targeting of resources to marginalized communities. Specifically, the article argues that omitting Roma as an ethnic category from past data gathering processes limits understanding of the commonalities and differences within and among Scottish communities, rendering entire populations invisible within broader empirical data and therefore restricting both identification of needs and effective resource allocation. Thus, the article presents a timely argument for the inclusion of Roma as an ethnic category in the 2021 Scottish census, while addressing issues within the census approach to data collection - including the impending digitization of the process. Through discussing and advancing the case for the inclusion of Romani communities in the 2021 Scottish Census, the paper also seeks to establish the current social context by chronicling the history of Romani migration and marginalization within Europe.

\section{Keywords}

- Census

- Inclusion

- Scotland

- Europe

- Identity

- Roma

- Gypsy

- Traveller 


\section{Introduction}

Drawing on Bassel and Emejulu's (2017) observations regarding the invisibility of minority ethnic communities within policy, coupled with a hypervisibility in media discourse, this paper repositions the same notion to the experiences of Romani communities in Scotland, elsewhere in the United Kingdom (UK), and in Europe more generally. Lane and Smith (2019) refer to "post racial policies", whereby specific communities are obscured within data, as well as "hyper-ethnic" approaches that aggressively target a given community in an often discriminatory manner. We argue that both approaches can be seen in Scotland with regard to Romani communities, and that this failure to provide appropriate opportunities for Romani individuals to be accounted for has resulted in a lack of adequate support for an often marginalized and stigmatized community. The current approach is also increasingly problematic given limited attention to digital literacy ahead of the implementation of the Digital First approach in future census collection processes. Understanding that this suggested binary experience of invisibility versus hypervisibility extends beyond policy and into portrayals of Romani individuals and communities in corporate media (both print and online press) and social media platforms, reference will be made to broader issues of stereotyping, discriminatory practices, and problematic representation. When addressing treatment of and discourse regarding Romani (in)visibility within academic research and government documents, a wealth of contemporary examples illustrates a lack of understanding of community-specific needs regarding, for example, language barriers, digital literacy, and internet access.

The article begins with a concise history of European Romani communities - including an acknowledgment of the contested accounts and divergent origins of Roma, Gypsy, and Traveller communities (see e.g. Acton 1974; Okely 1983; Clark 2001, Marcus 2016) and the persecution of these communities from the fourteenth century (Council of Europe 2012) through to the modern-day. ${ }^{[1]}$ Following this, we focus on the experiences of Romani communities in the UK and especially Scotland, and argue for the inclusion of Roma as a distinct ethnicity in the 2021 Scottish Census, while equally addressing the problematics of gathering ethnic data and the exclusionary process of digitizing the 2021 Scottish Census via the National Records of Scotland (2019) Digital First approach.

\section{Who are Roma, Gypsy, and Traveller People?}

Despite being a vast number of heterogeneous and differing communities, Roma, Gypsy, and Travellers are often clustered or merged within data sets and policy (see Scottish Government 2018), resulting in distinctions among communities being blurred within dominant discourses and individual differences and therefore being rendered invisible. Today, Roma, Gypsy, and Traveller communities present Europe's largest combined ethnic minority group with an estimated 10-12 million census sample size spread throughout the continent (Liégeois 1994; Council of Europe 2012; European Commission 2016), yet these communities are consistently one of the most socially excluded ethnic groups in Europe (Poole and Adamson 2013).

1 For example, recent hate crimes have been reported in Hungary (see e.g. Craig 2001; Koulish 2005; Halasz 2009) and Italy (see e.g. Woodcock 2010; ERRC 2019), among many other places. 
Tracing the lineage of Europe's present-day Roma communities, Acton $(1974,1)$ highlights Roma people leaving India almost 1,000 years ago and "moving along trade routes" during subsequent centuries towards Europe. While the "out of India" migratory theory remains contested (see Okely 1983), Bánfai et al. (2018) revealed that the impact of the Caucasus region on the genetic legacy of Roma people using genome-wide data supports Acton's (1974) claims by demonstrating Roma migration through the Caucasus region after originating from India prior to arriving in Europe just over a millennium ago.

Despite whatever similarities may exist among these communities, a nuanced understanding of the origins of each is essential. The Council of Europe (2012) contends that Travellers in Ireland and in Scotland may have ethnically distinct origins from Roma, with each considered to be indigenous communities to their respective nations. Williamson (1994) supports this, linking Traveller communities to hunter-gatherers from the Mesolithic period. However, Clark $(2001,112)$ points to Travellers being a nomadic group formed in the fifteenth century "from the intermarriage between local nomadic craftsmen and Romanies from France and Spain in particular". Given the lack of consensus regarding the origins or histories of Roma and Travelling communities, van Baar $(2011,1)$ echoes Belton's (2005) conclusion that there is no consistent Gypsy lineage by stating that Roma, Gypsy, and Traveller communities are a people "without a history". While not the focus of this article, such distinctions are important to illustrate that Roma, Gypsy, and Traveller communities are not homogeneous, and while communities may often share cultural practices, it must be recognized that each community is multi-layered (Mayall 2015), with unique identities, lifestyles, religions, and moral belief systems (Hamilton 2016).

\section{Terminology}

As with Collins' $(2017, \mathrm{xi})$ note that use of "minority women [...] renders an array of non-white women simultaneously hypervisible in the media", generic terminology pertaining to Gypsy, Roma, and Traveller people (e.g. "GRT") has often been controversial, given that it does not refer to a single homogenous group, and thus does little to acknowledge the distinct historical and cultural trajectories of these communities (Foster and Norton 2012; Sime et al. 2014). Levinson (2015) stresses the pejorative nature of the terminology, and indeed the use of the terms "Gypsy" and "Traveller" is an area of contested space, acceptable to some communities while others may find it offensive (D’Arcy 2017). For example, some European Roma reject the term "Gypsy" and prefer to self-identify as "Roma" (Mulcahy et al. 2017). In support of this, the Council of Europe (2012) ceased using the term Gypsy in official documents in 2005 at the request of international Romani associations which, as Levinson (2015) suggested, found the term "Gypsy" to be pejorative. In contrast, English and Welsh Gypsy families are often proud to be called Romani Gypsies or just Gypsies, whereas Scottish Travellers sometimes reject the terms "Gypsy" or "Roma", preferring to self-identify as either "Gypsy-Travellers", "Scottish Travellers", or "Travelling People” (Hancock 2002; Mulcahy et al. 2017).

Within the Scottish context and the use of "Traveller" within policy documents, Article 12 in Scotland $(2018,1)$ problematizes the nature of umbrella terminology. In the group's response to a Scottish Government (2018) consultation, they stated: 
[Traveller] ... brings together groups who do not identify as Traveller and/or do not have a mobile lifestyle [ie. Showpeople do not self-assign as Traveller and Roma are no longer nomadic]. Its use conflicts with other official terminology and as such could lead to a lack of understanding of differe[nt] cultures and traditions.

Similarly, many Irish Travellers and Scottish Travellers reject the term Gypsy and may also reject any suggested connection to communities who identify exclusively as Roma, while Romani Gypsies in England and Wales and Scottish Travellers have fought hard to be recognized as a distinct minority community (Social Marketing Gateway 2013). Dutton (1989) notes that previously Romani Gypsies were defined as an ethnic minority group by the Race Relations Act (1976). Irish Travellers subsequently were recognized as a minority ethnic group in 2000 (O'Leary v. Allied Domecq 2000; Race Relations [Amendment] Act 2000). Scottish Travellers were recognized only more recently as having a separate ethnic status in Scotland (K. MacLennan v. GTEIP 2008), thereby being granted protection under the Race Relations Act (1976) (Scottish Government 2014). ${ }^{[2]}$

Further compounding the issue is confusion over terminology within various research and policy documents. For example, a consultation on the rights of UK Gypsies and Travellers, on the one hand, highlights the movement of Roma people into the UK from the 1990s and then, on the other hand, cited evidence that 15 per cent of Gypsy/Romani young people achieved five or more GCSE grades yet the sample consisted of only Romani Gypsy young people and not Romani young people (Craig 2001). Confusion over terminology was also found in the Social Marketing Gateway report entitled "Mapping the Roma Community in Scotland" (2013), wherein they gathered data from all 32 councils, but it became apparent that respondents worked primarily with Gypsy/Travellers and provided responses for the Travelling community as opposed to migrant Roma.

Moreover, in January 2019 the authors consulted Iulius Rostas ${ }^{[3]}$ (personal communication, January 2019) on the National Records of Scotland Question Testing Survey. During this consultation with Rostas on the census testing questions concerning ethnicity, he expressed concern over how categories are created and under which heading minority ethnic communities are to be registered. For example, "Roma" has been placed under "White Other" by National Records of Scotland (2019); however, he noted that when one considers antigypsyism and the social exclusion many Roma people face, this is often "on skin colour", suggesting instead that Roma would be better placed under "mixed race/ethnicity", given the race-based discrimination often endured.

2 The Race Relations Act (1976) was repealed by the Equality Act 2010 (J. Brown 2018).

3 Associate Professor at Central European University and author of publications such as Ten Years After: A History of Roma School Desegregation in Central and Eastern Europe (2012) and Antigypsyism, Education and the Media: Ways Forward (2017) and editorin-chief of the Critical Romani Studies journal (2018). 


\section{Homogenous Persecution: A Historical Overview}

While Roma, Gypsy, and Traveller histories, origins, and identities remain contested, fragmented, and difficult to unpack due to a lack of written historical records (Matthews 2012), it is widely recognized that they are heterogeneous communities (Marsh 2013). While we have seen the ebb and flow of persecution and discrimination directed toward Roma, and varying per geopolitical context, their histories have largely been marked by discrimination, ostracism, persecution, and unequal access to social justice throughout the ages (Angus 1992; Hancock 2002; Acton and Ryder 2012; James 2014).

The first written record of Roma arriving in Europe appears in the fourteenth century (Council of Europe 2012) and evidence of European "gadje"[4] populations rejecting such communities begins shortly after their arrival (Taylor 2014) - with Berlin $(2018,184)$ suggesting they were considered "deviant". Allen (2018) argues that as the European political and economic landscape became more reliant on commerce and centralized funding revenue streams, public attitudes towards Romani communities changed as they commonly became viewed as subverting social norms. For example, due to their nomadic traditions, such communities were difficult for government authorities to track down for tax collection (Hancock 2000). The stereotyping of Roma and Traveller populations as "tax-dodgers" persists today (see e.g. Denson 2011; Reid 2015; Robinson 2016).

Across Europe, an increasing number of laws were passed during the fifteenth and sixteenth centuries that criminalized nomadism, unlicensed trading, and being caught sleeping in tents or trailers (HoughtonWalker 2014). The consequences of these "transgressions" resulted in "offenders" being systematically arrested with punishments including execution, forced labour, and whipping being commonplace (Allen 2018). In addition, many women were subjected to forced sterilization (Rodriguez and Araújo 2017). Romani persecution continued throughout Europe into the seventeenth century as seen by the penal transportation of Romani communities from England to the "new world" (Hancock 1987). While the eighteenth century saw Romani groups established as a distinct population that needed to be "improved" through assimilatory processes of population management (van Baar 2011). The nineteenth century in Finland saw the emergence of policies that sought to eliminate Romani culture and language through the use of forced labour and the segregation of Romani children by placing them in "Gypsy schools". Other measures included forcibly removing children from their families by placing them in state custody (Berlin 2018).

The twentieth century saw the genocide of more than 1.5 million Roma and Sinti (ERRC 2004b) during the Holocaust along with other minority groups such as Jewish people, members of the LGBTQ+ community, trade unionists, and people with disabilities (Zimmerman 1996; Aly and Heim 2003; Greenfields et al. 2018). Following the end of the Second World War and the rise of communism in many parts of Eastern Europe, the punitive and exclusionary practices towards Roma, Gypsy, and Traveller people across Europe continued and witnessed many states enforcing sterilization of women (ERRC 2004a), coerced resettlement, and segregated formal education in an attempt to convert these populations

4 Gadje is a term used by some European Roma to refer to non-Romani people (Kuiper 2019). 
in to what respective states perceive as productive workers (Guy 2009; van Baar 2011). Such persecution of Roma communities did not cease, neither with the fall of communist regimes nor with the shift to market economies and the "democratization" of Europe (Crowe 2008; Mirga 2009; Poole and Adamson 2013). Rather Roma communities continued to be vulnerable to racially motivated violence throughout Europe (see Bancroft 2001; Fekete 2014).

Consequently, it is important to acknowledge that given this sustained history of persecution, many individuals may remain cautious over identifying themselves as Roma within census data. Despite this, the inadequacy of state-funded support for self-managed projects as well as organizations working with or alongside Roma communities demonstrates the need to consider the introduction of "Roma" as a distinct ethnic category in nations where census data collects this information.

\section{Arrival and Treatment of Romani Communities in the UK}

The collapse of the Soviet Union in 1989 saw a number of Romani refugees fleeing persecution in Central and Eastern Europe and seeking asylum in the UK (Brown et al. 2013). However, their asylum claims often were denied (Ryder and Cemlyn 2016). It was not until 2004, with the expansion of the European Union (EU) to include A8 (Czech Republic, Estonia, Hungary, Latvia, Lithuania, Poland, Slovenia, and Slovakia) and A2 countries (Bulgaria and Romania) in 2007 that not only Roma but all Central and Eastern European citizens were granted the right to free movement within European Member States including the UK. Adamson and Poole $(2013,23)$, however, question whether Roma migration following EU expansion was genuinely voluntary, suggesting instead that Roma are a demographic that continue to be "pushed abroad" as opposed to being "pulled toward" employment or other opportunities.

The Immigration Act (1999) led to the establishment of the dispersal system of asylum seekers across the UK, placing asylum claimants in Local Authority, Housing Associations or private sector housing in areas of multiple deprivation against their will (Poole and Adamson 2003). If the claimant refused to be rehoused this would automatically result in being excluded from any welfare assistance - further perpetuating cyclical deprivation as asylum seekers are not allowed to gain employment while their claim is being processed. Compounding the issue is that responsibilities exist on a spectrum of reserved and devolved powers between the Scottish Government (Holyrood) and the UK Government (Westminster), further complicated by the administration of policy at the local council level. For example, Section 5 of the Scotland Act (1998) reserves employment, social security, and immigration policy areas to Westminster. By contrast, healthcare, education, children's services, housing, and policing are each devolved powers and include the provision of services to asylum seekers and A8 migrants who have no recourse to public funds.

The European Commission launched the Decade of Roma Inclusion in 2011 wherein EU member states were expected to devise "National Roma Integration Strategies" in order to address social exclusion (Rostas and Ryder 2012; Ryder and Cemlyn 2016). The European Commission (2011) also made explicit in its guidelines to member states that they ensured that a national Roma integration policy framework 
was in place in line with the Common Basic Principles on Roma Inclusion (2009) in order to use the European Structural and Investments Funds for the period 2014-2020. The European Commission $(2011,8)$ set the following criteria:

1. Sets achievable goals for Roma Integration to bridge the gap with the general population. These targets should address, as a minimum, the four EU Roma integration goals relating to access to education, employment, healthcare and housing;

2. Identify where relevant those disadvantaged micro-regions or segregated neighbourhoods, where communities are most deprived, using already available socio-economic and territorial indicators;

3. Allocate sufficient funding from national budgets, which will be complemented, where appropriate, by international and EU funding;

4. Include strong monitoring methods to evaluate the impact of Roma integration actions and a review mechanism for the adaptation of the strategy.

The UK Department of Communities and Local Government (2012), in their Progress Report produced by the ministerial working group on tackling inequalities experienced by Gypsies and Travellers, only included Roma within their considerations of education - excluding them from discussions on health, accommodation, and employment outcomes. While the UK National Roma Integration Strategy (described by the ERPC $[2012,22]$ as more akin to "sets of policy measures within wider social inclusion policies") was accepted by the European Commission, it largely ignored Romani-specific issues. Moreover, the strategy did not consider Romani communities dispersed across Scotland and failed to mention employment policies and interventions relating to recent arrivals to the UK. To date, the Scottish Government has yet to submit its own Roma Integration Strategy to the European Commission (Community InfoSource 2016). With the UK's imminent departure from the European Union following the 2016 Referendum (colloquially, "Brexit”), the UK and devolved Scottish governments may no longer be legally obligated to share the statistical results of the 2021 Census with the European Commission (National Records of Scotland 2018).

In 2011, the then Minister for Housing and Local Government, Grant Shapps, MP, provided evidence to the House of Commons European Scrutiny Committee arguing that a Roma strategy would impose unhelpful targets and add unnecessary reporting requirements (European Scrutiny Committee 2011). This came despite the European Commission (2011) making it explicit that targeted actions and sufficient funding were necessary as traditional social inclusion measures were failing to meet Romani-specific needs. Policy, however, continues to marginalize Roma from A8 and A2 countries. For example, there were transitional employment restrictions for newly arrived Romani and non-Romani migrants from A8 countries and, consequently, they had "no recourse to public funds" (Paterson et al. 2011). In 2011 when restrictions for A8 nationals were lifted, giving individuals the right to work and access welfare in the UK, restrictions still applied to A2 nationals (Social Marketing Gateway 2013). 


\section{The Census}

The ethnic group question was added to the UK census monitoring data in 1981, enabling local authorities to develop effective social policies to address inequality and measure the impact of various policies (Finney and Simpson 2009). In a report by Hills et al. (2010), entitled An Anatomy of Economic Inequality in the UK, the authors found that Gypsy and Traveller communities were absent from ethnic monitoring categories on surveys, resulting in a paucity of knowledge on the inequality that these communities face. The inclusion of Gypsies and Travellers in the 2011 census gathering process was therefore an important first step in addressing the inequality that these groups experience. However, different ethnic classifications were used on census questionnaires in England and Wales, Scotland, and Northern Ireland. In England and Wales, participants could self-ascribe as "Gypsy or Irish Traveller", whereas in Scotland the response category included "Gypsy/Traveller" and the equivalent category in Northern Ireland was "Irish Traveller" (Parliament and House of Commons 2017). These inconsistencies continue to permeate through policy in England, Wales, and Scotland. For example, in a recent House of Commons Library (2017) briefing paper the terms "Gypsy and Travellers" were used to capture Roma, Romani Gypsies, Irish Travellers, Scottish Gypsies/Travellers, and Welsh Gypsies/Travellers, as well as cultural Traveller identities. In a recent Scottish Government consultation, the term "Traveller" is used to describe Gypsy/Travellers, Roma, and Showpeople (Scottish Government 2017).

The 2011 combined UK census data sets identified circa 63,000 Gypsy, Roma, and Traveller people living in the UK with roughly 58,000 people in England and Wales self-ascribed as "Gypsy or Irish Traveller", around 4,000 people living in Scotland self-ascribed as "Gypsy/Traveller", and close to 1,000 people living in Northern Ireland identified as "Irish Traveller" (ONS 2013). However, this count is considered to be a gross underestimate as the Council of Europe (2013) has estimated a combined population total of between 150,000 and 300,000 Gypsy, Roma, and Traveller people currently living in the UK. Elsewhere, Brown et al. (2013) suggested that indigenous Romani Gypsy and Traveller population sizes match that of the Romani population (roughly 200,000); speculated that there may be combined numbers of indigenous groups and newly arrived Roma of between 400,000 and 500,000 in the UK; and emphasised the need for resources to support community members.

Matras $(2015,29)$, however, problematizes the estimations put forward by Brown et al. (2013), describing them as "abstract projections" and a methodology that not only lacked transparency but failed to engage directly with Romani communities. Matras also raised concerns regarding the criteria respondents utilized to identify Roma, which is significant due to confusion over terminology within the UK context, as the terms Roma, Gypsy, and Traveller often are conflated and treated as synonyms, while "Roma" often is conflated with "Romanian". Matras further criticized the authors very public dissemination of data on national television, which fuelled xenophobia. To this end, population figures for the most deprived ethnic minority community groups remain contested and underestimation persists.

Mulcahy et al. (2017) cite three factors to explain this underestimation: fear of racial prejudice and discrimination; low literacy rates; and institutional failure to include those in mobile housing. A further contribution to the low estimate is that the census excluded Roma as a response category, 
with census officials advising participants who would self-identify as "Roma" to select "White Other" (Mulcahy et al. 2017). Pertaining to Romani populations, Brown and Scullion (2014) estimate approximately 197,705 Roma living in the UK, with England suggested to have a Romani population of around 193,297; around 3,030 Romani migrants reside in Scotland, and circa 500 in Northern Ireland. Brown, Martin, and Scullion $(2014,23)$ cite a number of reasons for the gross underestimate including "collection instruments often recording nationality rather than ethnicity". Is it possible instead that the underestimate may be due to a lack of state will to engage all communities or on failure by the state to provide the option for Roma to identify? The Irish Traveller Movement in Britain (2013) argues precisely this, suggesting that the underestimate was due to the failure of the Office of National Statistics (ONS) to engage with marginalized communities.

The lack of census data presents serious challenges in developing effective policies and targeted services for Romani communities living in Scotland. According to the European Commission (2010, 24), the data deficit is "one of the biggest obstacles to the development, implementation, assessment and transferability of evidence based policies whose impact can be effectively evaluated". Indeed, without ethnically disaggregated data, policymakers will be unable to develop policies that promote equality of access and measure participation outcomes in the areas of health, education, housing and employment. When considering that the underestimate may be due to community members reluctance to self-identify (see e.g. Ofsted 2014; Mulcahy 2017; Scottish Government 2018), the current authors encourage policymakers and researchers not to hide behind the oft-quoted but unsubstantiated motif that Roma, Gypsy, and Traveller communities "do not want to engage" or "self-identify". This serves only to further pathologize Gypsy, Roma, and Traveller cultures and is an example of what Acton $(2016,4)$ terms "prejudiced neglect".

\section{The Need to Measure Population Sizes?}

The importance of measuring population sizes has long been recognized. The UK census, for example, allows the government to determine the resources needed in relation to education, employment, health, accommodation, transport, and social services based on the population size. Reliable and comparable data is vital in order to design effective legislation and policies across multiple indicators so as to put in place effective solutions to address social inequalities. The National Records of Scotland (2018) examined the effect of the census not being carried out on the misallocation of funds. An examination of the effects of the 2011 census not having taken place and instead using the results of 2001 census figures on NHS Health Board funding allocations estimated a misallocation of GBP 30-40 million in 2014-15 alone.

Equally, ethnic categorization and monitoring are contested ideas and processes, given that the relationships between ethnic categorization, public policy, and the behaviour of a given society are contextual, mutually constructive, and consistently in flux. The use of ethnic categories thus carries much social and political significance, which both can reflect and cause problems and inequalities between groups and actors (Simon, Piche, and Gagnon 2015). The socio-political context behind ethnonyms how and by whom ethnic and racial categories are set, and how they are officially presented as fixed and mutually exclusive when they are not, raises questions about both their usefulness and their intent (Safran 2008). Simon, Piche, and Gagnon (2015) discuss and compare six types of "data collection 
regimes" that can be observed in the collection of official diversity data. Two of the six regime-types observed are those that do not gather data on ethnicity in official statistical production, either for the purpose of national integration (erasing difference) or, conversely, in the name of multiculturalism. The four remaining regime-types do gather data on ethnicity - the authors define these four regimes as (1) counting to dominate, (2) counting in the name of multiculturalism, (3) counting for survival, and (4) counting to justify positive action ( $\mathrm{ibid.}$. 3). These regimes are not necessarily mutually exclusive - they can overlap and coincide, and importantly, they can be performing more than the function that is being claimed. In other words, intent does not equate to outcome, so data collection to ensure multiculturalism or positive action in actuality has the potential to contribute to domination, exasperate societal rifts, and produce policy with negative impacts.

We take these problems into account and acknowledge that the process of defining and collecting information about ethnicity and race is complex and messy, and not to be taken for granted. However, given the fact that Scotland and the UK do politically operate in such a manner where official data on ethnicity is gathered and then used to inform policy and funding decisions, we believe that the need for recognition, policy change, and funding when it comes to Scotland's Roma communities does involve a need to officially recognize Roma as an ethnic group, separate to Gypsies and Travellers. The Open Society Foundations has also emphasised the need to measure Romani population size in order to adequately allocate resources to Europe's most marginalized ethnic minority group:

The official invisibility of Roma people negatively affects public funding that help Roma communities with healthcare, education, employment, and housing. This invisibility also undermines the potential for Roma political participation and Roma led social change $(2013,1)$.

Looking particularly at education, January 2003 saw the Department for Education and Skills (DfES, 2003) in England and Wales revise ethnic monitoring categories, and young Gypsy, Roma, and Traveller people were categorized under "Traveller of an Irish Heritage" or "Gypsy/Roma” (DfES 2003). Such categories also appear in the Pupil Level Annual School Census Data (PLASC 2003-2008), now known as the School Census, thereby allowing the DfES to monitor and analyse the performance of young Gypsy, Roma, and Traveller people. In comparison, ethnic minority categorization in the Scottish Government's (2016) attainment data, wherein "Occupational Gypsy and Other Travellers" is included under "All other categories" makes no mention of Roma communities. This is problematic, for if we do not know how many Romani young people are attending schools in Scotland then we cannot bridge the education gap through targeted interventions and the provision of resources such as language support of dedicated staff members. The NRS (2018) emphasises the importance of data on proficiency in the use of English in relation to planning educational and translation services. However, ethnic monitoring categories in Scotland do not include Roma as a response category, making it difficult to measure language support needs, exclusion, and attainment, rendering young Romani people invisible when considering destination data. Accounting for low written and therein digital literacies among Romani communities as observed by Mulcahy et al. (2017), barriers to inclusion within future census data sets are likely to worsen as the process shifts online. 


\section{UK Romani Population Estimates}

While Roma have been excluded from Census 2011, there have been several notable attempts to estimate the size of the UK Romani population. In 2009, the European Dialogue conducted a mapping exercise of A2 and A8 Romani communities in England (European Dialogue 2009). A mixed methods approach was utilized and involved interviews and focus groups with Romani and non-Romani stakeholders as well as a nationwide survey sent to 151 Local Authorities in England. Statistical data derived from School Census figures in 53 Local Authority areas estimated there to be 24,101 Romani young people in England. The data gathered, however, from 103 Romani interviewees indicated that figure to be much higher, placing the estimate at 111,002. Due to the glaring inconsistencies, the authors proposed a minimum estimate of 50,000 Roma living in the England. Moreover, the mapping exercise found inefficient data collection across Local Authorities, and where Local Authorities had a good estimate of their Romani population, they were more readily able to respond to community members' needs. The research, however, was English specific.

When investigating the population size of Roma in the UK, Brown et al. (2014) distributed a selfcompletion questionnaire to all 406 Local Authorities in England, Scotland, Wales, and Northern Ireland - the results of which estimate a Romani population of 193,297. However, only eight Scottish Local Authorities responded to the consultation resulting in an estimate of 3,030 Roma living in Scotland (see Table 1). The methodology adopted by the researchers coupled with the relatively low response rate meant that aggregation was not possible. However, Brown et al's (2014) estimated population of 3,030 is supported by a mapping exercise of the Roma in Scotland during which the Social Marketing Gateway (2013) conducted an online consultation involving 31 Scottish Local Authorities (Argyll and Bute did not respond) in order to estimate the minimum and maximum size of the Romani population within their Local Authority.

Table 1. Romani Population by Council Area in Scotland

\begin{tabular}{ccc} 
Council Area & $\begin{array}{c}\text { Minimum } \\
\text { number of Roma }\end{array}$ & $\begin{array}{c}\text { Maximum } \\
\text { number of Roma }\end{array}$ \\
\hline Glasgow & 3,000 & 4,000 \\
\hline Edinburgh & 105 & 210 \\
\hline Fife & $\mathbf{6 0}$ & $\mathbf{6 0}$ \\
\hline North Lanarkshire & 30 & 60 \\
\hline Aberdeen City & 50 & $50+$ \\
\hline Falkirk & $\mathbf{2 0}$ & $\mathbf{2 0}$ \\
\hline Other 26 council areas & 539 & 543 \\
\hline Total & 3,804 & 4,946 \\
\hline
\end{tabular}

Source: Adapted from Social Marketing Gateway (2013).

This research, entitled Mapping the Roma Community in Scotland, indicated that the Local Authority areas of Fife $(\mathrm{N}=60)$ and Falkirk $(\mathrm{N}=20)$ estimated a maximum of 80 Romani individuals living in their 
localities. However, forthcoming research conducted with Fife Migrants Forum and Fife City Council's Education Department places the number of Roma in Fife and Falkirk to be between 2,000 and 3,000 (Hay, forthcoming). The disparity in numbers is problematic as research suggests councillors will not support the cost of additional services for a seemingly small amount of people - despite evidence that services are struggling to deal with the complex needs of Romani communities (Social Marketing Gateway 2013). In this sense, Roma become further marginalized as these seemingly small numbers rarely support prioritization of vital support and resources. The Social Marketing Gateway $(2013,34)$ argued that "it is unrealistic to develop new Roma-specific services", stating that "the objective should be to create bridges and pathways that can link Roma people into existing mainstream provisions". However, the disparity in population estimates demonstrates that such a stance is founded on inaccurate population figures and fails to consult with the targeted demographic.

\section{Census 2021 Developments in the Republic of Ireland, England, and Wales}

The work of Pavee Point Traveller and Roma Centre in the Republic of Ireland has been instructive as they have been comprehensively and strongly advocating for the inclusion of Roma in Ireland's census (see Pavee Point 2017a, 2017b). Pavee Point's role in engaging and increasing RGT communities' participation in Census 2016 was essential as it indicated an increase in Travellers self-identifying from 5.1 per cent in 2006 to a 37 per cent (circa 30,987) increase in participation in Census 2016 (Pavee Point 2016). The group provided information and knowledge to community members through informationsharing sessions, DVDs explaining the purpose and benefit of the census, a dedicated website on census fieldwork, and awareness-raising educational sessions among local Traveller organizations, identifying these challenges as an additional resource requirement by the Central Statistics Office (CSO). The group are currently involved in proposing a separate Romani category in Ireland's 2021 Census. In their submission to the CSO, entitled Towards an Ethnic Equality Question in Census 2021 (2017b, 17), Pavee Point draw attention to the continued omission and "statistical invisibility" of Roma in Ireland. Within their recommendations, Pavee Point call for the inclusion of Roma as a disaggregated category within Census 2021, as well as recognition that Roma are a community that continues to experience the highest levels of inequality across Europe and that gathering reliable statistics are a key step in being able to tackle these inequalities. The published minutes of the CSO's first Census 2021 Advisory Group meeting, held in 2017, show that there were several suggestions and strong support to add Roma as a separate option on the 2021 Census, and that it was under consideration and a subgroup has been set up to frame a revised question (CSO 2017). There has been no official announcement of the addition of the category, however.

In June 2015, the UK Office of National Statistics (ONS) launched a public consultation asking census users to share their views on a range of topics including ethnic identity classifications. In response a number of organizations such as Sheffield City Council, the Coordinator for UK Race and Europe Network, and the Discrimination Law Association put in a request for specific information on Romani communities. An ethnic group stakeholder follow-up survey was subsequently undertaken in November 2016 in order to further explore more specific ethnic group information. The survey yielded further requests 
for information on Roma from the National Federation of Gypsy Liaison Groups, Cornwall Council, Manchester City Council, Oldham Council, Tai Pawb, and London Borough of Redbridge citing that the additional data was needed for resource allocation, service planning and delivery, equality monitoring, and policy development (ONS 2018). There was a significant demand for a consistent and standardized approach to data collection across the UK so as to equip policymakers with essential information in order to make strategic and evidence-based decisions (Pavee Point 2017b).

Following this public consultation and research in December 2018, the UK Government released a Census 2021 White Paper setting out a clear proposal to include Roma as an ethnic category on the 2021 Census in England and Wales. The ONS plans to "work with the Roma population, assisting Roma organisations to provide support for local communities and raising awareness of the Roma response option" (UK Statistics Authority 2018b, 48). The White Paper outlines evidence-based justification for this inclusion, stating that:

There is evidence that Roma are a group of particular policy interest for stakeholders to help ensure, when developing local lettings policies, that their needs are met without unintentional discrimination. There is also evidence that data on Roma are needed in planning services, for example to help plan school places, understand language (UK Statistics Authority 2018b, 49).

Research conducted by the ONS, including user focus groups, indicated that while some Roma would tick the "Gypsy or Irish Traveller" box, there was disagreement and uncertainty about this option, in terms of identification as well as variance in whether participants considered "Gypsy" a derogatory term. Overall it was found that the "Gypsy/Irish Traveller" option does not meet user requirements and reduces the "quality and utility of the data", and that users identify with the Romani option with significantly more ease. The document also states that "locating the specific response option within the White category caused least confusion" (ibid.).

This recognition of the need for a separate Romani option on the 2021 Census in England and Wales has been welcomed positively by organizations working with Roma across the UK and Ireland (Travellers Times 2019), as well as by the authors of this article. However, we would assert that the inclusion of the Roma tick-box under the "White" or "White Other" category is problematic. In the Equality Impact Assessment for the 2021 Census, published in tandem with the previously mentioned White Paper, the ONS repeats its recommendation to include a Roma response option, stating that "gathering details on ethnic group and national identity are crucial to understanding inequality associated with race in the UK" (UK Statistics Authority 2018a, 12). We agree with this statement, and consequently express concerns that locating a Romani option under "White" or "White Other" will not meet this demand.

\section{Census 2021 Developments in Scotland}

Echoing Pavee Point's (2017b) recommendations, the Scotland's Ethnic Group Question format should be compatible with the UK Census format. Scotland's census is conducted in-line with the Census Act 1920 (UK Parliament 1920), with the 2001 Scottish census the first undertaken post-devolution. The NRS, in their report entitled Plans for Scotland's Census 2021 (2018), indicated that the main ethnicity 
classification changes being considered for further testing at the time of writing was the inclusion of response options for Scottish Showpeople, Roma, Sikh, Jew, and an open text response box under the African category. While these developments are welcome in principle, there are concerns over digital inclusion. Scotland's 2021 Census will be Digital First and the census will be conducted primarily online and a paper questionnaire where online completion is not possible (NRS 2018). While the NRS states within their report that it is essential that all households complete their census return, no consideration is given to language support needs in completing the census. This is problematic due to the high levels of illiteracy among Romani populations who are unable to read and write in their own language, let alone English, indicating the need for language support resources so that Romani communities can participate in Census 2021 (see e.g. Mulcahy et al. 2017).

Evidence was submitted by the current authors to the NRS consultation in December 2018 which provided support from individuals and groups within the following organizations for the inclusion of Roma as an ethnic monitoring category:

Petition respondents included: University of Dundee, University of Edinburgh, University of Glasgow, University of Strathclyde, University of the West of Scotland, Glasgow Caledonian University, GMB Union, Unite the Union, Unison, Glasgow City Council Education Services, the Scottish Nationalist Party, the Scottish Greens, Glasgow City Council Social Work Services, and Friends of Romano Lav.

\section{0.(In)Visibility of Romani Communities and the Digital First Approach}

Collins (2017, xi) suggests "Western democracies have long expressed a fascination with and disdain for the designated minority ... in their midst". She hypothesises that the term "'minority' [...] renders an array of non-white [people] simultaneously hypervisible in the media", yet simultaneously blurs diverse cultural, religious, or ethnic backgrounds, therein erasing subtlety from political discourse and policy debate. Bassel and Emejulu $(2017,13)$ further suggest that "under austerity, minorit[ies] are disproportionately disadvantaged due to their already existing precarity". Focused efforts therefore are required from authorities to achieve best practice when conducting population-centred research to account for the additional barriers faced by particular communities. Common barriers can include command of the dominant language (see Bloch 2007; Worth et al. 2008; Netto et al. 2010; Tang 2016), and broader social marginalization (see Frazer 2005; Ravensbergen and VanderPlaat 2010). This can be applied to the experiences of Roma, Gypsy, and Traveller communities across the UK and across Europe more generally, and this paper specifically investigates this notion with regards to Romani communities in Scotland. The Digital First approach set to be utilized by the National Records of Scotland in conducting the 2021 Scottish Census, this article argues, fails to address several such barriers.

These communities and the structural disadvantages they face remain invisible within policy, statistics, resource allocation, and equality discourse (Morris 1999). Yet at the same time, Roma, Gypsies, and Travellers are hypervisible in the media, with negative stereotypes and representations permeating through media 
reports which then leads to the entrenchment of discriminations in public discourses and institutions (Morris 2000). For example, the Govanhill area in Glasgow, which is the home to the highest concentration of Romani families in Scotland, is often the focus point of negative media attention, characterized as "reeling from claims of child trafficking, muggings and decay" (The Scottish Sun 2018), with "crime" and "horror" being linked implicitly or explicitly to Romani communities residing in the area. In late 2017 a number of UK media outlets such as The Times (November 2017) and The Scottish Sun (November 2017) made unsubstantiated claims of Romani families in Govanhill selling their children into prostitution (Aitchison 2017; McKenna 2017). In summary, "hyper-visibility fosters hyper-surveillance and discrimination" (Collins 2017, xi).

Collins (ibid.) adds that such representations position particular minority communities as "either incapable of assimilation [...] or as unwilling to assimilate". Specifically applying similar notions to the experiences of Romani communities in Scotland, Marcus (2016) cites Trepagnier (2006) in acknowledging "well-meaning White people who consider themselves as non-racist and who work with minority ethnic groups" who through failure to recognize their position of privilege or recognize the significance of poverty and sustained oppression in countries of origin (see Ringold et al. 2004), and whose emphasis on assimilation rather than integration can in fact recycle racialized motifs to broader society - therein denying political agency to individuals with expert knowledge through lived experience.

Illustrating this point, in 2018 the Scottish Government (2018) adopted the term "Traveller" to refer to all Roma, Gypsy, and Traveller groups within their publication Improving Educational Outcomes for Children and Young People from Travelling Cultures. However, "Traveller" itself remains a contested term, with Simandl (2006) suggesting that it ascribes a Traveller lifestyle to those who may no longer travel either voluntarily or due to forced settlement as a result of exclusionary policies such as the (1994) Criminal Justice and Public Order Act (Greenfields and Smith 2019). For example, while some Roma, Gypsy, and Traveller people continue to travel, the majority of Roma (circa 80-85 per cent) in Europe and Irish Travellers in Ireland (circa 80 per cent) are largely sedentary (Council of Europe 2012), as living a nomadic lifestyle has become far too difficult due to wider socio-economic changes (Allen 2018). LevineRasky $(2018,314)$ further contends that Roma are "a group unjustly regarded as inherently mobile".

Less is known of Roma, Gypsy, and Traveller communities "inherent mobility" within the Scottish context. The Scottish Government's $(2015,37)$ comprehensive analysis of the 2011 Census identified that 33 per cent of "Gypsy/Travellers" owned their own homes, 40 per cent lived in social housing, and 14 per cent lived in a "caravan or other mobile temporary structure", therefore problematizing any allusions of mobility. Due to lack of census data pertaining to the Romani population, however, less is known about their living conditions. In their report "Where Gypsy/Travellers Lived" the Scottish Parliament Equal Opportunities Committee $(2013,2)$ briefly touches on Romani accommodation. The report did not cover Roma due to the paucity of evidence relating to this migrant community. The report did refer to a dire account of living conditions on arrival in Scotland wherein Roma are living in "privately rented accommodation, and although they pay taxes, and very high rents, they are suffering from appalling conditions of overcrowding".

In contrast, the Scottish Government (2018) cited research by Scottish Traveller Education Programme (STEP 2016, 4) entitled Mobile Children, Young People and Technology Project, which used the terms 
"mobile family" and "mobile communities" to describe various Roma, Gypsy, Traveller, and Showpeople identities despite evidence to suggest that many communities are now largely sedentary (Council of Europe 2012). In exploring young people's use of technology, the researchers recruited 19 young people in primary schools who identified as Slovak Roma $(\mathrm{N}=6)$ in Glasgow and Gypsy/Traveller $(\mathrm{N}=13)$ in Edinburgh, the Highlands, and Ayrshire. Acknowledging low literacy rates, the authors explicitly state within their methodologies section that the research design "reflected anticipated low written literacy and communication levels and placed emphasis on oral and visual forms of participation and expression" (STEP 2016, 15). Digital technology use was ubiquitous amongst all young people within the aforementioned study; however, the authors noted that there may be variability in access to the internet. The small sample size raises concerns over generalizability, parental literacy, digital literacy rates, and finally parental language barriers, data that would be relevant in the design and planning of Census 2021 and the Digital First approach in particular. Despite these limitations, the Scottish Government (2018) chose to emphasise the use of digital technology in education and largely overlook more pressing accessibility and language support needs.

Within their Digital First approach toward improving the educational outcomes of "Traveller" children, The Scottish Government (2018) also ignored Article 12 in Scotland's response to the pre-publication consultation. Article 12 in Scotland, comprised of Traveller and gadje team members, with strong links to Traveller communities in Scotland, voiced several recommendations concerning literacy support and digital access. In response to the inaccessibility of the consultation process itself the organization advised that while "responses are welcomed from members of communities who may have literacy/language issues, the document in its current format could prove inaccessible [suggesting that] an 'easy read' or audio version would have ensured wider engagement" (Article 12 in Scotland 2018). The organization proceeded to critique the Scottish Government's heavy reliance on technology for support in working with Roma, Gypsy, and Traveller young people due to issues around internet accessibility, stating that "internet access [phone and broadband] is patchy at best in much of rural Scotland [thereby] impact[ing] on young people's ability to engage". The organization further advised that a number of parents and guardians may have low level literacy and may consequently be unable to support young people in the use of technology.

Not only did the Scottish Government (2018) omit the response submitted by Article 12 in Scotland, but they also failed to look further afield at research by Scadding and Sweeney (2019) exploring digital access among Gypsy and Traveller communities in the UK. Sweeney et al.s, sample $(\mathrm{N}=50)$ consisted of 17 Romani Gypsies, 15 Irish Travellers, 1 Welsh Traveller, 8 New Travellers, 8 Travellers and 1 English Traveller. The research revealed high rates of digital exclusion, with a mere 38 per cent of Gypsies and Travellers having access to a household internet connection, if housed. Moreover, Scadding and Sweeney $(2019,5)$ found that 36 per cent of Gypsy and Traveller people "[could not] use technology" and 52 per cent of participants "did not feel confident using technology".

Despite the impending digitalization of the census process, to date no research has been conducted on Romani adults' access to the internet. Though National Records of Scotland (2018b) state that hard copies of the census form will be available during the 2021 collection process, no indication has been made on how paper surveys will be distributed nor has any advice been given regarding language 
support for census participants. While the number of Romani community members who are able to speak, read, and write English in the UK remains unknown, fieldwork by Brown and colleagues (2016) in six locations across the UK allows for further evidence on language needs. In their research using focus groups with 159 self-identified Romani individuals across Glasgow, Leicester, London, Oldham, Salford, and Sheffield the authors found universal consensus among participants for access to English language classes and, for many, access to English language courses was restricted. with participants also identifying barriers related to online job applications and a widespread inability to use computers. Due to lack of language acquisition support needs, Romani community members may not have digital literacy in any language - preventing the use of online translation software such as Google Translate. Language support therefore will be crucial in enabling many individuals from Romani communities to complete the census form during the 2021 Scottish Census process.

\section{Conclusion}

This article was inspired, in part, by Bassel and Emejulu's (2017) volume Minority Women and Austerity, and in much the same way as Collins (2017, xiv) praised the authors, this paper "refus[es] to collapse minority [communities] into an undifferentiated mass in which one group's experiences can easily be substituted for those of another". Similarly, as Collins (2017, xiii) advocates, the authors believe that the communities pushing for their inclusion within the Scottish 2021 Census "do not need others to explain their situations to them", rather as witnessed in current movements from the Scottish Showmen's Guild the communities pushing for inclusion as distinct ethnic categories are "agents in their own lives" and thus best placed to problematize current inclusion practice. Consequently, the co-authoring team is formed by a range of individuals from within and external to the Scottish or UK Romani populations, yet in much the same way bell hooks (1984) proposes, we work towards the "multi-dimensional gathering" of community members, educators, activists, policymakers, and academics towards greater inclusion in the Scottish political context and beyond. Therefore, to conclude, we stress that omission of Roma as an ethnic category from data gathering processes limits understanding of the commonalities and differences within Scottish communities and renders entire populations invisible within broader empirical data and policy interventions. Such invisibility restricts both identification of needs and effective resource allocation. We argue that Scotland should follow England and Wales by including Roma as an ethnic identity in the 2021 Census. However, rather than including this option as a subcategory of "White Other", as has occurred in the English and Welsh census, any Romani option should be included under the category of "Mixed Race/Ethnicity" in order to acknowledge the racialized aspects of antigypsyism and broader racism that affect communities and individuals based on their often non-white racial heritage. 


\section{References}

Acton, Thomas, and Andrew Ryder. 2012. "Recognising Gypsy, Roma and Traveller History and Culture." In Gypsies and Travellers: Empowerment and Inclusion in British Society, edited by Joanna Richardson and Andrew Ryder. Bristol: Polity Press.

Adam, Herbert. 2015. "Xenophobia, Asylum Seekers, and Immigration Policies in Germany." Nationalism and Ethnic Politics 21 (4): 446-464.

Allen, Daniel. 2017. “Roma: Is Discrimination Natural?” In Social Work Skills, edited by Kish Bhatti-Sinclair and Chris Smethurst. Bristol: Policy Press.

- 2018. "Resilient Cultural Transmission in a Hostile State. In Transnational Resilience and Change: Gypsy, Roma and Traveller Strategies of Survival and Adaptation, edited by Dan Allen, Margaret Greenfields, and David Smith. Cambridge: Cambridge Scholar Publishing.

Allen, Daniel, Margaret Greenfields, and David Smith. 2018. Transnational Resilience and Change: Gypsy, Roma and Traveller Strategies of Survival and Adaptation. Cambridge: Cambridge Scholars Publishing.

Aly, Gotz, and Susanne Heim. 2003. "Architects of Annihilation: Auschwitz and the Logic of Destruction." London: Phoenix.

Article 12 in Scotland. 2018. "Response to: Improving Educational Outcomes for Children and Young People from Travelling Cultures.” Angus: Scotland.

Bancroft, Angus. 2001. “Closed Spaces, Restricted Places: Marginalisation of Roma in Europe." Space and Polity 5 (2): 145-157.

Bánfai, Zsolt., Valerián Ádám Pöstyeéni Etelka, Gergely Büki, Márta Czakó, Attila Miseta, and Béla Melegh. 2018. "Revealing the Impact of the Caucasus Region on the Genetic Legacy of Romani People from Genome-wide Data." PLoS ONE 13 (9): e0202890. https://doi.org/10.1371/journal.pone.0202890

Bărbulescu, Horia. 2012. "Constructing the Roma People as a Societal Threat. The Roma Expulsions from France." European Journal of Science and Theology 8 (Supplement 1): 279-289.

Bassel, Leah, and Akwugo Emejulu. 2017. Minority Women and Austerity: Survival and Resistance in France and Britain. Bristol: Policy Press.

Beattie-Smith, Sarah. 2013. "Offline and Left Behind: Digital Exclusion amongst Scotland's CAB Clients, Citizens Advice Scotland.” http://bit.ly/2oIKtF9

Bloch, Alice. 2007. "Refugees in the UK Labour Market: The Conflict between Economic Integration and Policy-led Labour Market Restriction." Journal of Social Policy 37: 21-36.

Brown, Philip, Daniel Allen, Sindy Czureja, Liviu Dinu, Szcymon Glowacki, Gabi Hesk, Sylvia Ingmire, Philip Martin, Orsolya Orsos, Maria Palmai, and Terezia Rostas. 2016. "Supporting Roma Voices." University of Salford. https://www.salford.ac.uk/_data/assets/pdf_file/0008/1155608/SRV-Final-Report-Dec-2016.pdf

Brown, Philip, Liza Scullion, and Philip Martin. 2013. "Migrant Roma in the UK: Population Size and Experiences of Local Authorities and Partners." Sustainable Housing \& Urban Studies Unit, University of Salford.

Cahn, Claude, and Peter Vermeersch. 2000. "The Group Expulsion of Slovak Roma by the Belgian Government: A Case Study of the Treatment of Romani Refugees in Western Countries." Cambridge Review of International Affairs 13 (2): 71-82. 
Castle-Kanerova, Mita. (2002) "Migration and Poverty: The Case of the Slovak Roma." Social Policy and Society 1 (2): 165.

Craig, Gary. 2011. “The Roma: A Study of National Policies.” Brussels: European Commission. Available online at: http://www.york.ac.uk/inst/spru/research/pdf/EURoma.pdf

Clark, Colin Robert. 2001. “Invisible Lives’: The Gypsies and Travellers of Britain.” Unpublished.

Collins, Patricia. Hill. 2017. "Foreword." In Minority Women and Austerity: Survival and Resistance in France and Britain, edited by Leah Bassel and Akwugo Emejulu. Bristol: Policy Press.

Community InforSource. 2016. “The Roma Community in Scotland 2016.” Scottish Churches Racial Justice Group.

Council of the European Union. 2009. “Common Basic Principles on Roma Inclusion.”

http://register.consilium.europa.eu/doc/srv?l=EN\&f=ST\%2010394\%202009\%20

INIT

Council of Europe. 2012. "Descriptive Glossary of Terms Relating to Roma Issues."

Coyle, Matt. 2018 "In the Ghetto: Families Fear Govanhill Could Be bulldozed within a Decade amid Claims Gangs Unleash Terror on Dilapidated Streets.” The Scottish Sun, 4 August 2018. Available at:

https://www.thescottishsun.co.uk/news/scottish-news/3025241/govanhill-crime-squalor-investigation

Crowe, David. M. 2008. "The Roma in Post-communist Eastern Europe: Questions of Ethnic Conflict and Ethnic Peace." Nationalities Papers 36 (3): 521-552.

DCLG (Department for Communities and Local Government). 2012. "Creating the Conditions for Integration." London: Communities and Local Government.

Denson, Bryan. 2011. "Portland Gypsy Leader Accused of Filing False Tax Return, Faces Potential Prison Term.” Oregon Live. Available at: https://www.oregonlive.com/portland/2010/12/portland_gypsy_leader_accused.html

Department for Education and Skills (DfES). 2003. "Aiming High: Raising the Achievement of Minority Ethnic Pupils." London: DfES.

Department of Justice and Equality. 2017. “National Traveller and Roma Inclusion Strategy 2017-2021.” Ireland. http://www.justice.ie/en/JELR/National\%20Traveller\%20and\%20Roma\%20Inclusion\%20Strategy,\%2020172021.pdf/Files/National\%20Traveller\%20and\%20Roma\%20Inclusion\%20Strategy,\%202017-2021.pdf

Eliason, Antonia. 2016. “With No Deliberate Speed: The Segregation of Roma Children in Europe.” Duke Journal of Comparative and International Law 27: 191-241.

Equality. 2011. "From Segregation to Inclusion. Roma Pupils in the United Kingdom, A Pilot Research Project." http://equality.uk.com/Education_files/From\%20segregation\%20to\%20integration_1.pdf

European Roma Policy Coalition. 2012. "Analysis of the National Roma Integration Strategies." http://cms.horus. be/files/99935/MediaArchive/policy/Final\%20ERPC\%20Analysis\%2021\%2003\%2012_FINAL.pdf

ERRC. 2004a. "United Nations: Hungary Coercively Sterilized Romani Women." Budapest: European Roma Rights Centre. http://www.errc.org/press-releases/united-nations-hungary-coercively-sterilised-romani-woman

_ 2004b. "The Situation of Roma in an Enlarged European Union.” In Roma Holocaust: Recollections of Survivors." Budapest: Roma Press Centre Books.

European Commission. 2011. "Communication from the Commission to the European Parliament, the Council, and the European Economic and Social Committee and the Committee of the Regions: An EU Framework for National Roma Integration Strategies up to 2020." 
. 2014. "Directorate-General Regional and Urban Policy 2014-2020 Policy and Legislation Inter-institutional relations DRAFT Guidance on Ex Ante Conditionalities.” http://ec.europa.eu/regional_policy/what/future/pdf/ preparation/part2_guidance_ex-ante_conditionalities_guidance.pdf

European Dialogue. 2009. “The Movement of Roma from New EU Member States: A Mapping Survey of A2 and A8 Roma in England." http://equality.uk.com/Resources_files/movement_of_roma.pdf

European Scrutiny Committee. 2011. "Integration of Romani." http://www.publications.parliament.uk/pa/cm201012/cmselect/cmeuleg/428-xxvi/42809.htm

Farnell, Richard. 2001. "Faith Communities, Regeneration and Social Exclusion: Developing a Research Agenda." Community Development Journal 36 (4): 263-272.

Fekete, Liz. 2014. “Europe against the Roma.” Race \& Class 3: 60-70.

Finney, Nissa, and Ludi Simpson. 2009. "Sleepwalking to Segregation”?: Challenging Myths about Race and Migration. Bristol: Policy Press.

Frazer, Hugh. 2005. "Setting the Scene Europe-wide: The Challenge of Poverty and Social Exclusion." Community Development Journal 40 (4): 371-384.

Gould, Robert. 2015. "Roma Rights and Roma Expulsions in France: Official Discourse and EU Responses." Critical Social Policy 35 (1): 24-44.

Greenfields, Margaret, and David Smith. 2018. "Resisting Assimilation: Cultural Trauma, Survival and Adaptation to 'Alien' Accommodation forms: The Case of British Gypsy/Travellers in Housing." In Transnational Resilience and Change: Gypsy, Roma and Traveller Strategies of Survival and Adaptation, edited by Daniel Allen, Margaret Greenfields, and David Smith. Cambridge: Cambridge Scholars Publishing.

Guy, William. 2009. "Roma: Living Conditions, Social Perception and State Policy in the Macro-region of 'Eastern Europe' before and after 1989." Südosteuropa Mitteilungen 2: 54-65.

Halasz, Katalin. 2009. “The Rise of the Radical Right in Europe and the Case of Hungary: 'Gypsy Crime' Defines National Identity?” Development 52 (4): 490-494.

Hancock, Ian. 2000. “The Emergence of Romani As a Koiếne' outside of India.” In Scholarship and the Gypsy Struggle: Commitment in Romani Studies, edited by Thomas Acton. Hatfield: University of Hertfordshire Press.

- 2002. We Are the Romani People. Hatfield: University of Hertfordshire Press.

Hills, John, Mike Brewer, Stephen Jenkins, and Ruth Lister. 2010. "An Anatomy of Economic Inequality in the UK." London: Government Equalities Office.

Hogan, Patrick. 2016. “Bridging the Digital Divide, Citizens Advice Scotland.” http://bit.ly/2oIPltM

hooks, bell. 1984. Feminist Theory: From Margin to Center. London: Routledge.

Horne, Marc. 2017. “Children Sold for Sex on Streets of Govanhill.” The Times, 17 November 2017. https://www.thetimes.co.uk/article/children-sold-for-sex-on-streets-of-govanhill-rkrvkcczp

Houghton-Walker, Sarah. 2014. "Representations of the Gypsy in the Romantic Period." Oxford: University Press. Irish Traveller Movement in Britain. 2013. "Gypsy and Traveller Population in England and the 2011 Census." London: Irish Traveller Movement in Britain.

James, Zoe. 2014. "Hate Crimes Against Gypsies, Travellers and Roma in Europe." The Routledge International Handbook on Hate Crime. London: Routledge. 
Kisby, Ben. 2010. “The Big Society: Power to the People?” Political Quarterly 81 (4): 484-91.

Kelso, Michelle, and Daina S. Eglitis. 2014. "Holocaust Commemoration in Romania: Roma and the Contested Politics of Memory and Memorialization." Journal of Genocide Research 16 (4): 487-511.

Koulish, Robert. 2005. "Hungarian Roma Attitudes on Minority Rights: The Symbolic Violence of Ethnic Identification.” Europe-Asia Studies 57 (2): 311-326.

Kuiper, Kathleen. 2019. “Roma (People).” https://www.britannica.com/topic/Rom\#ref46705

Lane, Pauline, and David Smith. 2019. "Mid-term Review - UK Roma National Integration Strategy: Roma at the Intersection of Ethnic-inclusive, Post-racial and Hyper-ethnic Policies.” Journal of Contemporary European Studies. https://doi.org/10.1080/14782804.2019.1626226

Liégeois, Jean-Pierre. 1994. “Roma, Gypsies, Travellers.” Strasbourg, France: Council of Europe.

MacLaughlin, Jim. 1998. "The Political Geography of Anti-Traveller Racism in Ireland: The Politics of the Exclusion and the Geography of Closure." Political Geography 17 (4): 417-435.

Marsh, Adrian. 2013. “Gypsy, Roma, Travellers: An Animated History.” The Open Society Foundation. https://www.opensocietyfoundations.org/voices/gypsies-roma-travellers-animated-history

Matras, Yaron. 2015. "Use and Misuse of Data on Roma: A Comment on the Salford Study on Roma Migrants." In: Zeitschrift für internationale Bildungsforschung und Entwicklungspädagogik 38: 29-30.

Matthews, Jodie. 2012. "Romanies/Gypsies, Roma and Irish and Scottish Travellers: Histories, Perceptions and Representations." Connected Communities. https://ahrc.ukri.org/documents/project-reports-and-reviews/ connected-communities/romanies-gypsies-roma-irish-and-scottish-travellers

McGarry, Aidan, and Helen Drake. 2013. “The Politicization of Roma as an Ethnic 'Other': Security Discourse in France and the Politics of Belonging." In The Discourses and Politics of Migration in Europe, edited by Umut Korkut, Gregg Bucken-Knapp, Aidan McGarry, Jonas Hinnfors, and Helen Drake, 73-91. New York: Palgrave Macmillan.

McGillivray, David, Nick Jenkins, and Sophie Mamattah. 2017. "Rapid Review of Evidence for Basic Digital Skills. University of the West of Scotland.” https://digitalparticipation.storage.googleapis.com/reports/Tackling Digital_Exclusion_Literature_Review.pdf

Mirga, Andrzej. 2009. "The Extreme Right and Roma and Sinti in Europe: A New Phase in the Use of Hate Speech and Violence." Roma Rights Journal 1: 5-9.

Morris, Rachel. 1999. "Current Developments: The Invisibility of Gypsies and Other Travellers." Journal of Social Welfare and Family Law 21 (4): 397-401.

Morris, Rachel. 2000. “Gypsies, Travellers and the Media: Press Regulation and Racism in the UK." Communications Law 5 (6): 213-219.

Mulcahy, Ellie, Sam Baars, Kate Bowen-Viner, and Loic Menzies. 2017. "The Underrepresentation of Gypsy, Roma and Traveller Pupils in Higher Education: A Report on Barriers from Early Years to Secondary and Beyond.” Research brief. King's College London.

Murray, Laura. 2017. "Child Sex Horror: Children Are Being Sold for Sex by their Parents on Streets of Glasgow" The Scottish Sun, November 17, 2017. https://www.thescottishsun.co.uk/news/1850898/children-are-being-soldfor-sex-by-their-parents-on-streets-of-glasgow

National Records of Scotland. 2018. "Plans for Scotland's Census 2021.” 
Netto, Gina, Raj Bhopal, Nicole Lederle, Jamila Khatoon, and Angela Jackson. 2010. "How Can Health Promotion Interventions Be Adapted for Minority Ethnic Communities? Five Principles for Guiding the Development of Behavioural Interventions." Health Promotion International 25 (2): 248-257.

Office for National Statistics. 2018. "Freedom of Information: Inclusion of Roma in the 2021 Census." https://www. ons.gov.uk/aboutus/transparencyandgovernance/freedomofinformationfoi/inclusionofromainthe2021census

Okely, Judith. 1983. “The Traveller-Gypsies.” Cambridge: Cambridge University Press.

Parliament. House of Commons. 2017. "Gypsies and Travellers. (HC 08083). London: The Stationary Office." http://researchbriefings.parliament.uk/ResearchBriefing/Summary/CBP-8083\#fullreport

Paterson, Lindsay, Laura Simpson, Lorraine Barrie, and Jitka Perinova. 2011. "Unequal and Unlawful Treatment: Barriers Faced by the Roma Community in Govanhill When Accessing Welfare Benefits and the Implications of Section 149 of the Equality Act 2010." Govanhill Law Centre Report.

Pavee Point. 2016. "Pavee Point Traveller and Roma Centre Impact Report.” Dublin: Pavee Point Traveller and Roma Centre. https://www.paveepoint.ie/wp-content/uploads/2015/04/Impact-Report-2016_NOV17_W.pdf

Pavee Point and Traveller Roma Centre. 2017a. "Policy and Practice in Ethnic Data Collection and Monitoring." Dublin: Pavee Point Traveller and Roma Centre.

—. 2017b. “Towards an Ethnic Equality Question in Census 2021.” Dublin: Pavee Point Traveller and Roma Centre.

Race Relations Act. 1976. http://www.legislation.gov.uk/ukpga/1976/74

Race Relations (Amendment) Act 2000. http://www.legislation.gov.uk/ukpga/2000/34/contents\#

Ravensbergen, Frances, and Madine VanderPlaat. 2010. "Barriers to Citizen Participation: The Missing Voices of People Living with Low Income.” Community Development Journal 45 (4): 389-403.

Richardson, Joanna, and Janie Codona. 2018. "Blame and Fear: Roma in the UK in a Changing Europe." Journal of Poverty and Social Justice 26 (1): 95-112.

Reid, Sue. 2015. "It's a Good Time for Us to Come Begging in Britain: Romanian Gipsy Couple Arrive on $£ 38$ Flight and Make $£ 800$ on Streets of London in One Weekend to Wire Home to their Family." Daily Mail.

https://www.dailymail.co.uk/news/article-3372590/It-s-good-time-come-begging-Britain-Romanian-gipsy-pairfly-make-hundreds-pounds-weekend-home.html

Ringold, Dena, Mitchell Orenstein, and Erika Wilkens. 2004. "Roma in an Expanding Europe: Breaking the Poverty Cycle." Washington, D.C.: The World Bank.

Robinson, Julian. 2016. “The Really Far-right Party Making Gains in Europe: Slovakia’s Kotleba Uses Nazi Salutes, Blames All Crime on Gypsies and Wants to Return the Country to a 'Hitler Puppet." Daily Mail. https://www.dailymail.co.uk/news/article-3949304/Slovakia-comes-grips-proudly-neo-Nazi-party.html

Rodriguez, Silvia M., and Marta Araújo. 2017. "The Semantics of (Anti-) Racism in the Governance of NonEuropeanness: An Introduction.” Patterns of Prejudice 51 (1): 1-8.

Rostas, Iulius. 2017. "Antigypsyism, Education and the Media: Ways Forward." Identities 24 (6): 760-768. DOI: $10.1080 / 1070289 X .2017 .1380267$

Rostas, Iulius, and Andrew Ryder. 2012. "EU Framework for National Roma Integration Strategies: Insights into Empowerment and Inclusive Policy Development in Gypsies and Travellers: Empowerment and Inclusion.” In British Society, edited by Joanna Richardson and Andrew Ryder. Great Britain: Policy Press. 
Ryder, Andrew, and Sarah Cemlyn. 2016. "Monoculturalism, Austerity and Moral Panics: Assessing Government Progress of Addressing Gypsy, Traveller and Roma Exclusion." Journal of Poverty and Social Justice 24 (2): 143-55. http://dx.doi.org/10.1332/175982716X14650295704777.

Safran, William. 2008. "Names, Labels, and Identities: Sociopolitical Contexts and the Question of Ethnic Categorization." Identities 15 (4): 437-461. DOI: 10.1080/10702890802201743

Scottish Government. 2014. "Gypsy/Travellers." http://www.scotland.gov.uk/Topics/People/Equality/gypsiestravellers

_. 2015. "Gypsy/Travellers in Scotland: A Comprehensive Analysis of the 2011 Census." https://www.gov.scot/publications/gypsy-travellers-scotland-comprehensive-analysis-2011-census

_ 2016. "Summary statistics for attainment, leaver destinations and healthy living." Accessed online 26 January 2018 from http://www.gov.scot/stats/bulletins/01225

_. 2017. "Consultation on Improving Educational Outcomes for Children and Young People from Travelling Cultures: Report on the Responses to the Consultation (Edinburgh)."

https://consult.gov.scot/support-and-wellbeing/improving-educational-outcomes-for-children/results/travellereducation---analysis-report-9.10.17.pdf

_. 2017. “Scotland's Equality Evidence Strategy 2017-2021.” Edinburgh. https://www.gov.scot/binaries/content/documents/govscot/publications/statistics-publication/2017/07/scotlandsequality-evidence-strategy-2017-2021/documents/00522512-pdf/00522512-pdf/govscot\%3Adocument.

Scottish Parliament Equal Opportunities Committee. 2013. "Where Gypsy/Travellers Live. First Report (Session 4).” https://www.amnesty.org.uk/files/scot_parl_eoc_where_gypsy_travellers_live_2013.pdf

Scadding, Joe, and Sarah Sweeney. 2018. "Digital Exclusion in Gypsy and Traveller Communities in the UK." Brighton: Friends Families and Travellers. https://www.gypsy-traveller.org/wp-content/uploads/2018/09/ Digital-Inclusion-in-Gypsy-and-Traveller-communities-FINAL-1.pdf

Simhandl, Katrin. 2006. “Western Gypsies and Travellers' - 'Eastern Roma’: The Creation of Political Objects by Institutions of the European Union." Nations and Nationalism 12 (1). https://doi.org/10.1111/j.1469-8129.2005.00232.x

Simon, Patrick, Victor Piche, and Amélie Gagnon. 2015. “The Making of Racial and Ethnic Categories: Official Statistics Reconsidered." In Social Statistics and Ethnic Diversity, edited by Patrick Simon, Victor Piche, and Amélie Gagnon. Cham: Springer, 1-14.

Taylor, Becky. 2014. Another Darkness, Another Dawn: A History of Gypsies, Roma and Travellers. London: Reaktion Books Ltd.

Travellers Times. 2019. "Roma to Be Included in 2021 Census." Hereford: Rural Media. https://www.travellerstimes.org.uk/news/2019/01/roma-be-included-2021-census

UK Parliament. 1920. Census Act 1920.

UK Statistics Authority. 2018a. "Equality Impact Assessment for the 2021 Census." London: UK Statistics Authority/Office for National Statistics, December 2018.

_ 2018b. "Help Shape Our Future: The 2021 Census of Populations and Housing in England and Wales." London: HM Government, December 2018.

Van Baar, Huub. 2008. "The Way out of Amnesia? Europeanisation and the Recognition of the Roma's Past and Present." Third Text: Critical Perspectives on Contemporary Art and Culture 22 (3): 373-385. 
Nicola Hay • Luke Campbell • Colin Clark • Marta Kowalewska • Lynne Tammi • Brigitta Balogh

Van Baar, Huub. 2011. "Cultural Policy and the Govermentalization of Holocaust Remembrance in Europe: Romani Memory between Denial and Recognition." International Journal of Cultural Policy 17: 1-17. https://www.tandfonline.com/doi/pdf/10.1080/10286631003695539?needAccess=true

White, Douglas. 2016. "Digital Participation and Social Justice in Scotland: Understanding and Tackling the Digital Divide." http://bit.ly/2q6gXy0

Williamson, Duncan. 1994. The Horsieman: Memories of a Traveller 1928-1958. Edinburgh: Canongate Press.

Woodcock, Shannon. 2010. "Gender As Catalyst for Violence against Roma in Contemporary Italy." Patterns of Prejudice. 44: 5, 469-488, DOI: 10.1080/0031322X.2010.527444

Zimmermann, Michael. 1996. Rassenutopie und Genozid: Die nationalsozialistische "Lösung der Zigeunerfrage." Hamburg: Christians Verlag. 